\title{
THE MEANINGS OF UNIVERSITY SOCIAL COMMITMENT. AN APPROACH TOWARDS CONSTRUCTING THE STATE OF THE ART
}

\author{
Carina Andrea Gerlero* \\ Rosario National University - Ministry of Education of Santa Fe, Argentina. \\ cgerlero@hotmail.com \\ Received on: 07/04/2014 Accepted on: 11/04/2014 \\ Translated from the Spanish by \\ Agustina F. Casero \\ Body of Translators, Rosario National University (UNR), Argentina
}

\section{Resumen}

El presente artículo (1) tiene como objetivo identificar y analizar las perspectivas teóricas sobre el Compromiso Social Universitario (CSU) a partir del relevamiento del conocimiento producido en el período 2007-2013, con el propósito de precisar qué se entiende por CSU y a qué modelo de Universidad suscribe. Se indagan relaciones entre éste y la tradición reformista de las universidades públicas argentinas, principalmente en lo referente a su función social. Se analizan las similitudes y diferencias entre el CSU y la Responsabilidad Social Universitaria (RSU), tratando de discernir si se trata de una cuestión semántica o si se sostienen en diferentes valores y conceptos.

Se identifican algunos principios obligados al momento de referirse al CSU, tales como: la definición de proporcionar educación universitaria de calidad igual para todos; la democratización y la orientación solidaria de las acciones universitarias, a través de las funciones de docencia, extensión, in-

* Department of Education Planning and Articulation. Ministry of Education, Province of Santa Fe, Argentina. Specialist in High Education Policies and Management (CEIUNR). PhD candidate in Education of Experimental Sciences (FBCB - UNL). 
vestigación y gestión; la necesidad de establecer un diálogo con la sociedad, para contribuir, conjuntamente, a desarrollar la cultura y los procesos de integración regional, disminuir la exclusión y brechas de desigualdad, profundizar la democracia y el bien común, asumir un compromiso ético con la transformación y construcción social.

\section{Palabras Clave:}

Universidad - Función Social - Democratización - Diálogo - Compromiso ético.

\section{Abstract}

The object of this paper is to identify and analyze the theoretical perspectives about University Social Commitment (USC) based on a survey of the knowledge produced between 2007-2013, in order to specify the meaning of USC and to which model of University it subscribes. The relationship between USC and the tradition of reformist Argentine public Universities is assessed; mainly with regard to its social function. The similarities and differences between USC and University Social Responsibility (USR) are analyzed in order to decide whether this is a semantic matter or whether these are notions based on different values and concepts.

Some significant principles are observed when referring to USC, such as: the decision to provide a quality university education equal for all; the democratization and solidarity-based orientation of university actions by means of its teaching, extension, research, and management functions; and the need to establish a dialogue with society so as to jointly contribute towards developing culture and regional integration processes, reducing exclusion and inequality gaps, deepening democracy and the common good; as well as making an ethical commitment to social transformation and construction.

\section{Keywords:}

University - Social function - Democratization - Dialogue - Ethical commitment.

\section{On the Constitution of the Field of University Social Commitment}

In Latin America, public universities are simultaneously sustained and organized on the basis of two wide models: the professionalizing University and the scientific University, which make their very own imprint as a result of the ideas derived from the 1918 Reform. Its postulates were a starting point for the processes of democratization of HEls, involvement of university agents in national political and social issues, interrelation between Latin American 
universities and innovation in academic programs. Progressively, Reformist Universities supported open and free access, academic freedom, access to faculty positions through competitive examination, university autonomy and autarchy, participation of faculty, students and graduates in university and college government, university extension, modernization of curricula and the faculty's pedagogic strategies, among others.

Although this model of a Reformist University was settled among university agents, it did not have a continuous development throughout history. In general terms, it was fostered during democratic periods and reduced during periods with governments installed through dictatorships. From that moment to our days, during democratic periods, universities have strengthen their ties with society through different formats, models or strategies, which will only be dealt with tangentially here, since the time frame exceeds the limits of this paper.

Based on the analysis of available documents and bibliography from 2007 to 2013 , we can observe, in the last few years, the configuration of a field of specialized academic production on Higher Education (HE) in reference to USC. Between 2007/2008 there were certain events that seemed to determine the emergence of this field. In Latin America and the Caribbean, the 2008 Regional Conference on Higher Education (CRES) has clearly occupied a central place, since it defined the prospects for HE in the region. Views from the CRES, along with views arisen in conferences from other regions, are part of the input that came into play during the 2009 World Conference on Higher Education (WCHE) held in Paris. These perspectives have enabled an understanding of the meanings of USC and have enriched theoretical productions, debates and research, while favoring the configuration of SC as an autonomous concept, in the field of university HE.

It is interesting to review the approaches arisen during different exchanges about university-related topics which serve as precedents for the Conferences. In this respect, we place the 1996 CRES held in La Habana and the 1998 WCHE, which took into account, among other aspects, the document prepared by UNESCO in 1995: "Policy Paper for Change and Development in Higher Education". This document resulted in the need to strengthen equity, quality, pertinence and internationalization in the field of HE. These stages showed the influence of policies typical of the '90s and, although there were views concerning the relation between University and society, there was still no structuring of them in terms of USC.

More recently, we can mention the International Conference of Latin American and Caribbean University Rectors: "THE SOCIAL RESPONSIBILITY OF LATIN AMERICAN AND CARIBBEAN UNIVERSITIES", held at the Federal University of Minas Gerais on September 2007. The declaration issued by the Rectors who took part $(2007$, p. 2) suggests: "Conceiving the social commit- 
ment of universities (...) as an implementation of institutional policies whose premise is education as a human right, a public good, which takes into consideration the social factor, in accordance with quality, pertinence, relevance, inclusion and equity values". On the other hand, they recognize that the work of the 1998 WCHE on the pertinence of HE allows considering USC in relation to the scope of an education which takes into consideration the social factor. They understand that, to achieve this purpose, it is necessary to construct a kind of knowledge that contributes to reducing those inequities strengthen by globalization processes and guarantying those rights which favor a better quality of life. They also propose different topics to be addressed by the university agenda, such as committing to expand coverage while meeting the need for quality social inclusion, leave HE out of GATS (General Agreement on Trade in Services) agreements and promote a solidarity-based internationalization of HE in Latin America and the Caribbean, among others. Nevertheless, the main prospect on the agenda lies in the issue of "promoting a qualitative leap in the social commitment of Universities, stimulating the generation of strategic changes", in a way that allows moving from poorly systematized low profile isolated actions to programmatic lines which take part in the missions of Higher Education Institutions (HEI).

Within the Conference of Rectors, we highlight Miguel Rojas Mix's presentation on "Social Commitment of Latin American and Caribbean Universities". He suggests that the root of USC is to provide quality education, on equal basis, for all citizens. He specifically refers to USC as:

\section{(...) a broad commitment that spreads over different fields related to the reproduction and improvement of the social model: equity, science, profes- sional efficiency, culture and identity, ideological pluralism, social ethics, preservation of historical memory and universality of knowledge, as well as the creation of a critical mass (Rojas Mix, 2007, p.179).}

Moreover, he points out that the roles University must embrace to fulfill this commitment are: to develop culture and cultural integration, as historical memory forges the imaginary in the construction of identity and enables critical thinking in a globalized world; to direct its action towards the common good in service of the nation, which gives pertinence to HE, since it allows to distinguish and contextualize what is better for its culture and what strengthens its development; to teach values, develop and defend democracy, in a way that allows for a recovery of the relation between democracy -in the political field-, philosophy -in the field of knowledge- and the ability to live and think rationally in society; to reduce the gaps and inequities that threaten social justice, leaving aside the liberal tendency that promotes the substitution of democracy by the market and of the political factor by the economical factor.

Rojas Mix (2007) states that the development of USC requires the cons- 
truction of a constant dialogue between University and different local, national and regional social agents. On this level, it is important the role of University as guarantor of the access to higher education based on equal opportunities and the teaching of values, which favors critical thinking while defending and building individual and collective rights.

The International Conference of Latin American and Caribbean University Rectors also included the presentation of Roberto Tejada Reyna, Rector of the Autonomous University of Santo Domingo. In his exposition, entitled "Proposals for an Agenda on the Social Commitment of University", Tejada Reyna (2007) stated that the mission and philosophy typical of University place it as an institution with SC. Regarding the agenda, the following issues were highlighted: the need to build it in accordance with the social agenda, since this will provide meaning and pertinence to university actions; the commitment to shape empathetic and value oriented professionals; the development of university curricula invested in improving people's quality of life; active participation in the achievement of the Millennium Development Goals established by UNESCO, especially when it pertains to the promotion of an equitable distribution of wealth and the eradication of extreme poverty, hunger, illiteracy and child mortality, among others.

On November 2007 the 9th Latin American Congress of University Extension took place in Bogotá, Colombia. The main conference, in charge of Carmen García Guadilla, entitled "Social Commitment of Universities", referred to USC as something inherent to university purposes, and analyzed the different ways of understanding and naming it, especially from the mid 20th century to the present.

Her presentation states that during the ' 50 s and '60s, USC represented the developmentalist ideology in the sense that education would allow for underdeveloped countries to overcome this situation. The premise was that more education equals more productivity and social mobility. According to García Guadilla, that is the reason some authors have named this period "the age of innocence", since education alone cannot fulfill this role. She recovers Paulo Freire's view regarding the idea of university extension as a process of dialogical and horizontal communication between University and society, as opposed to the unidirectional set-up, where universities "give" and society "receives".

She places "the age of skepticism" during the " 70 s, highlighting the emergence of socio-educational critical theories, influenced by the reproductivism of Bordieu and Passeron as well as by the idea of Darcy Ribeiro, who proposes replacing the "traditional university" with the "necessary university", which favors University's commitment towards society. The ' 80 s are described as a "lost decade" due to the economic crises that took place at the beginning of the globalization process. She interprets that the influence of critical theories diminished while some participatory action approaches emerged, which, in 
the field of HE, were associated with the production and distribution of knowledge regarding the social environment. The '90s vindicate the approaches of Freire, Echavarría, Ribeiro and other Latin American referents in view of the new scientific paradigms. This period questions certainty and determinism and values social subjectivity, social agents and democracy as the "expansion of reflective consciousness in every area of social interaction". On the one hand, this enables a new understanding of the world, based on diversity, pluralism, values of solidarity, responsibility and mutual respect. On the other hand, it grants value to the production of contextualized, integrated and interdisciplinary knowledge. Nevertheless, at the same time, the neoliberal policies of HE are also established during this decade.

Finally, she characterizes the 21 th century as the "age of social commitment", understood as a commitment to human and sustainable development in order to face globalization and its resulting inequalities. She expresses that:

Social commitment as a requirement is one of the key elements of the late 2010s. Social commitment must overcome the limitations present in the concept of extension, vindicating a necessary contextualization of knowledge, an interaction with society, shared learning processes oriented towards transdisciplinarity, increasingly viable interactive processes between education and society, a new perception of networks as collective learning organizations and an education without borders (García Guadilla, 2008, p.34).

We should stress that these meetings taking place at a regional level have converged in two broad Conferences. The Regional Conference on Higher Education in Latin American and the Caribbean, on June 2008 in Cartagena de Indias and the World Conference on Higher Education: "The New Dynamics of Higher Education and Research For Societal Change and Development", on July 2009 in Paris.

The CRES' Final Declaration (2008, p.2) expresses that the main purpose is "to establish a scenario that makes it possible to articulate in a creative and sustainable manner policies that strengthen the social commitment, quality and pertinence of higher education and the autonomy of Universities". As regards USC, the following points are highlighted:

[Its position regarding] the humanistic character of higher education (...) [and the resulting orientation] towards the comprehensive training of persons, citizens and professionals, able to approach [the needs of the context] with ethical, social and environmental responsibility (...) and who can actively, critically, and constructively participate in society.

[The fostering of] respect for and defense of human rights (...) [by including 
them in] educational programs, as well as in the priorities of research, extension and inter-institutional cooperation. (...)

[The decision to] move forward in establishing a more active relationship [between Universities and their contexts].

[The linking of quality] to both pertinence and responsibility toward sustainable development [of society]. (...)

[The need for] an academic model marked by the examination of problems within their contexts; the production and transfer of the social value of knowledge; joint work with communities; scientific, technological, humanistic and artistic research based on an explicit definition of the problems being addressed, of fundamental interest for national or regional development, and the well-being of the population; an active dissemination effort aimed at educating for citizenship, rooted in respect for human rights and cultural diversity; extension activities that enrich education, helping to detect problems for the agenda of research, and that create areas for joint action involving diverse segments of society, especially the most neglected. (Declarations of the Regional Conference on Higher Education in Latin American and the Caribbean, 2008, p.6)

The communique of the 2009 WCHE also exhibits views related to USC or USR when referencing:

The social responsibility [of higher education] to advance our understanding of multifaceted issues, which involve social, economic, scientific and cultural dimensions and our ability to respond to them. (...)

Higher education must not only give solid skills for the present and future world but must also contribute to the education of ethical citizens committed to the construction of peace, the defense of human rights and the values of democracy. (...)

Member States, working in collaboration with all stakeholders, should develop policies and strategies at system and institutional levels to (...) ensure adequate investments in higher education and research to reflect growing expectations and societal needs. (Communiqué of the World Conference on Higher Education, 2009, pp. 2-8).

Contributions made by the participants present at these Conferences, Meetings and Congresses, whether made by speakers or university representatives, contributed to starting a configuration of the field of USC. Moreover as the subject was addressed by the heads of HEls, it was easier to include it in the university agenda. The fact that this happened within spaces of dialogue marks a clear position in the field of education. There is great value not only in their calling for action but in the institutional commitment taken on from different university functions towards the development of concrete policies rooted in social commitment for every country and territory affected by their actions. 
As a result of these meetings, the view of USC was installed in the university agenda and is still present today through different efforts and actions carried out by HEls on the complex broad topics comprised in USC. This strengthens the thought that USC is a commitment inherent to University as well as a political and ideological principle affecting all university functions.

We notice that the relation between USC and the social and cultural values of education is focused on reducing the negative impacts of globalization and other neoliberal policies. Moreover, the hope is to reduce the inequalities faced by our societies through increasing citizens' participation in the decision-making process concerning issues and situations that involve them. The access of more young people to a comprehensive university education, a humanistic educational model, the development of research pertinent to social needs as well as extension practices which favor a dialogue between University and society are the basis for achieving these goals.

\section{Theoretical Approaches to University Social Commitment and University}

\section{Social Responsibility}

USC is conceived in a polysemic manner, having multiple different meanings. This section aspires to analyze the approaches and conceptions in question so as to understand the meaning attributed to USC. It could be thought that the different ways of conceiving USC are related to different ways of understanding the University, its mission and the actions that define which should be its core functions. Specifying the meaning of SC calls for mentioning the underlying view as regards the "Idea of University" and the meanings assigned to University HE.

It would be interesting to divide the concepts according to its underlying theoretical approaches and observe how other aspects of USC come into play, in an attempt to enrich the analysis. In this respect, we will, on the one hand, address the conceptions that refer to USC and USR as a strategy based on the University's social function and non-transferable mission of building the society it falls within. On the other hand, we will analyze the conceptions built from a logic near to Corporate Social Responsibility (CSR), which, as a result, link USR with the University's role of environmental impact management, assessment and accountability.

\section{Social Commitment and the Social Function of University}

This section will address perspectives that relate USC to the social role of University. Here we place the conception of Miguel Rojas Mix (2007), who expresses the need for a quality education for all that enables the education of a "social professional" committed to situations typical of a specific historical, political and social time and context (2). 
On a similar line of analysis, in the context of a research project on University Social Commitment (3), Cecchi, Lakonich, Perez and Rotstein (2009, pp.11-12) state that USC is the basis for discussing the objectives of University and the ways in which Latin American Universities link their actions to national and regional issues, especially those concerning the most vulnerable segments. They place the emergence of the idea of USC in Argentina during the 1918 University Reform and observe that this idea is not a constant feature in Argentina. It is present during democratic periods and absent during periods of successive military coups d'état. They identify the scientific-technological paradigm as an obstacle to USC, since it conceives academic roles dissociated from their context of development.

The authors suggest thinking USC from three principles: "Quality Education for all" (as established by UNESCO), "Purpose" and "Identity" (both suggested by Rojas Mix). Regarding the purpose of University HE, they refer to what kind of professionals should be formed, and that they support, as well as Rojas Mix, the idea of a social professional, who would act guided by the principle of solidarity. On the topic of University Identity, they propose relating it to peace, culture and the reproduction and improvement of a social model of integration. They also retrieve different contributions made by Taborda and Freire which favor the idea of USC as:

(...) a way of writing the cultural world, and that means a way of "writing it", where this writing -even when we consider thought coming from previous readings and writings, never isolated nor individual - is a creative act, an act which is not restricted to a premature closure of meaning behind experience, life and the world, but which registers the opening of other possible worlds and experiences built on the University-Society relation (Huergo, 2006, cited by Cecchi et al., 2009 , p. 41)

In turn, Boaventura de Sousa Santos (2005, p. 78) suggests that Universities must assume their URS and accept being affected by social demands, especially by those coming from groups with little power to command them. $\mathrm{He}$ reflects on what enables meeting the challenges of USR, i.e. autonomy, academic freedom and appropriate institutional conditions, and understanding that regional and local contextual challenges cannot be faced in a rigid or general manner.

Moreover, the author suggests that the University must regain its legitimacy through a broad USR program that includes action lines related to access, extension, research-action, the ecology of knowledge, the University-Public School relation and the University-Industry relation.

The following is a brief analysis of each line. We notice that, based on its position, SC has to do with going beyond massification in order to move towards in the democratization of access. To this end, it is necessary to enable 
free access and financial aid (scholarships) for working-class students; the joint work between Universities and public schools to promote the integration of both systems and improve teaching and learning conditions in the fields of pedagogy and science; and positive action measures that confront discrimination associated to racial, ethnic and social vulnerability conditions. Furthermore, another central aspect proposed is the revision of spread knowledge to avoid elitist, meritocratic or privilege-based conceptions in present and future generations. Here it is important that the education of teachers be focused on the public sphere rather than on principles promoted by institutions subject to modalities of the education market.

Moreover, he notices that SC emerges whenever there are extension activities ideologically and politically based on "building social cohesion, deepening democracy, fighting social exclusion and environmental degradation, advocating for cultural diversity". (By Sousa Santos, Ibid.:67). In this line of argument, research-action is worth it as long as it contemplates and involves the participation of non-university social agents in its design and execution. The author also thinks that the ecology of knowledge deepens research-action while acting as an inverse extension: it allows for knowledge originated in different spheres — popular, layman, traditional — to engage in dialogues with the scientific and humanistic knowledge produced at University. These strategies may provoke a solidarity-based reorientation of the University-society relation.

On the other hand, he points out that the concepts of "knowledge society" or "knowledge economy" attempt to center the production of knowledge from a neoliberal paradigm so as to aid corporations, therefore increasing their profits. This conception turns knowledge into a private or privatizable good, exchangeable in the market. On the contrary, an action based on USC demands for the agenda of scientific research to be established and regulated according to multiple social needs, enabling wider research areas and exchanges between universities and companies, which do not necessarily involve an academic dependency or the financial survival of HEls.

Another contribution relevant to the topic of USC, which strengthens the idea of its connection with a social function, is the one made by Cruz Ayuso and Sasia Santos (2008), as they focus the attention of University Commitment on the construction of citizenship as well as on the power of these institutions to influence society and enable actions that can change situations of great social vulnerability. In this sense, they understand that the education of responsible citizens, the contribution to social development and the generation of new knowledge contribute to SR without being an end in themselves. These aspects enable the transformation and construction of society from the point of view of ethics and social justice. Therefore, they argue that thinking the concept of responsibility from the field of CSR and from the concepts of 
corporate management confuses and restricts the scope of USC, since University is not supported on the principle of economic "utility", nor should its social action be reduced to aid or charity actions. They suggest thinking the concept of responsibility from the following dimensions of analysis:

A primary consequentialist meaning which, as regards the decision-making process, stresses the analysis of consequences and calls upon taking responsibility for the potential impacts derived from this process, especially the negative ones. A secondary contractual meaning which stresses the importance of everyone's responsibility —people and organizations-, as significant actors or agents of a society. Finally, a third prospective stage which highlights the a priori aspect of such duty and the need to be concern about, deal with and take responsibility over things. This stage refers to people or organizations willing to take over, through their actions or activity, the regeneration of our unequal and unfair societies (de la Cruz Ayuso \& Sasia Santos, Ibid.:35).

They suggest moving forward towards a third meaning of responsibility, one that will enable an understanding of University as an institution of society and of its commitment with social matters as well as its modalities of interaction with and intervention in social issues.

We can notice that the conceptions expounded so far focus on how to involve the University, on the basis of its essential functions, in the construction and transformation of the societies they are part of. Here lies the relation between SC, social function and a model of progressive University, actively involved in contextual liaisons.

In this sense, the most relevant proposals have to do with the challenge of educating a social professional and the need for a solidarity-based reorientation of the link between University and society. An interaction that, within a framework of dialogue and articulation of policies, enables a positive transformation of living conditions for the most vulnerable segments, promotes a democratic coexistence of ideas, and values the contributions arising from social and cultural diversity. These proposals allow for an observation of how USC links itself with the principles of the 1918 University Reform as well as of the need to deepen the reach of reformist principles, adapting actions to address present challenges.

\section{University Social Responsibility from a Corporate View}

This section will review the approaches that link USR with CSR. On this line of analysis, we place the conception of Torres Pernalete and Trápaga Ortega (2010), who establish a link between the social role of University (4) and the present definition of university extension, USC and USR, among others; although they place mainly the most recent precedents of USR as a concept 
in the late ' 90 s, on occasion of the escalation of globalization. They suggest that the paradigm of USR emerges as a result of the need for a new social contract between University and Society, promoted by the University Network for Ethics and Social Development, of the IDB, which implemented the Support Program for Initiatives of USR, Ethics and Development in 2006. Here USR is seen as a concept formulated in terms of impact management (5), related to the fundamental functions of University: teaching, research, extension and management.

Moreover, the authors suggest that the central aspect of USR is the configuration of an ethical conduct which includes a joint responsibility with the environment. In this sense, they understand that University, besides creating professionals and providing an educational service, is an institution "serving all that is relevant for the individual and for society in general". They consider that a socially responsible University addresses its own needs as well as social needs; promotes learning to achieve sustainable human development; should worry about its own activities and member's quality of life; should adopt a critical position and a position of permanent evaluation, and should have a USR management body.

The conception of François Vallaeys, de la Cruz and Sasia $(s, f)$ refers to USR in terms of impact management and recovers the concepts of CSR so as to apply them to USR. They define USR as "aiming to reposition University in society lining up its four processes (management, teaching, research and extension) with the mission, values and social commitment of University" (:22). They notice that USR is rooted in ethics and actions which, in practice, can make its development possible.

On the general impacts that universities should manage, they propose to encourage a "responsible campus", promoting an organization culture of University that recovers and strengthens labor, social and environmental rights while fostering human and environmental development as well as increasing social capital. In relation to University's own impacts, on the one hand, they consider those of an educational nature, which stand for the education of citizens and professionals responsible to society. On the other hand, they refer to cognitive and epistemological impacts, which tend to a social appropriation of knowledge and include the participation of non-academic agents in research practices.

They understand that USR defines and improves USC as it creates a need for management at University and provides the tools to this end. Additionally it promotes a dialogue with and participation of different university and non-university agents.

Nonetheless, Saravia and Escobar (2010) relate SR to addressing the needs of the population, to ethics and human rights, and to the challenge of contributing to common good and sustainability. They analyze USR as part 
of the SR inherent in organizations from different origins(social, political and economic) as well as in the State. They identify that the notion of SR, which was initially developed for business organizations, has extended to other spheres. They also consider that, at present, the labor markets and the globalization of communications call for knowledge, causing some differences with the previous forms of "value creation" in the market. The economic value of information, although intangible, constitutes the main generator of economic value. Therefore, they understand that social justice is related to an equitable distribution of knowledge focused in the needs of society.

Margetic and Suarez (2006) analyze the Statutes of National Universities as regards their mission, social function and university extension, so as to identify how institutional modalities of commitment with national issues present themselves. They notice that the "ought to be" present in the Statutes, generates tension between aspirations of universality and particularity, and do not always agrees with ongoing university policies. Furthermore, they acknowledge that "this attitude of paying attention to their own contexts is defined as social responsibility, sensitivity and, principally, as a solidarity-based commitment with the community" (:27).

The perspectives outlined in this section recover the need to tie University actions with its environment, in order to favor sustainable human development and social justice. Although they think of USR as a modality that enables such tie, the stress is on how the management of these impacts is carried out in HEls.

The authors express the need to implement processes and mechanisms of institutional assessment, accountability, organizational good practices and advertising of action. Thus, they understand that there is a social contract established between University and society, as well as an ethical management and organization culture built taking into consideration labor, social and environmental rights. These concepts, originated within the paradigm of CSR, can contribute to strengthening institutionality and, therefore, to achieving social goals through different functions of University. But they can also constitute an element that links its practices to market rules. Therefore, strong monitoring is required so as to prevent a blurring of the main objectives pursued by SR.

The contribution of USR lies in emphasizing the need to manage so as to transform. In order to achieve a real contribution to their objectives, university projects and actions require strategic planning. Nevertheless, the challenge is to prevent management from becoming an end in itself, denaturing its raison d'être to be established as a privileged source of authority that sets university objectives and, therefore, leading education towards a neoliberal model. 


\section{Concluding Thoughts}

The most important contribution from the perspective of USC, as something inherent to the social function, is concerned with addressing University objectives as related to what is external to the institution. The idea is to think the objectives based on University autonomy while focusing on society. This position places citizens and the social factor first, so as to transform living conditions, favor social inclusion and build more democratic and fair societies. Although University processes do not lose their specificity, they are organized and developed so that their basic functions build upon what is specific of a discipline and upon how such discipline relates to its professional, cultural and social context. Therefore, dialogue-based contributions as well as the articulation of actions between political, social and State agents become important. This idea is founded in a humanistic and progressive model of Education and University, which, in the case of our Latin American identity, follows the ideological and political line launched by the 1918 reformists. The main challenge for these proposals is to avoid remaining a mere declaration of principles and become real in everyday practices.

The analysis on the field of USC, concerning both the events which made its emergence possible and the contributions from research and theoretical conceptions, consolidates its indissoluble link with the social function of University. Thus, we identify some essential principles when referring to USC, such as:

- The decision to provide quality University education for all, on equal basis.

- The democratization and solidarity-based orientation of University actions, through teaching, extension, research and management functions.

- The need to establish a dialogue with society, so as to jointly contribute to developing culture and regional integration processes, reducing exclusion and inequality gaps, and strengthening democracy and the common good.

- An ethical commitment to social transformation and construction.

These principles are neither exclusive nor contrast with the specificity of University -in terms of a place for the circulation, transfer and construction of knowledge. The idea is to place the political meaning of University in the framework of the social function. In contrast with the conceptions that hold the neutrality of knowledge and science, USC engages and involves HEls: it allows them to be part of social, political, economic and cultural processes. Being part of it should not be interpreted as being the only one responsible for such processes, but it means that University cannot be thought apart from them.

Moreover, USC involves challenges placed within university processes, so the political meaning of education is in question here. The idea is to identify whether the goal is to provide a collection of knowledge related to certain technical tools which allow for access to productive and service delivery pro- 
cesses, or if it is to develop culture and favor the acquirement of social and cultural goods, or just a combination of both of them.

An attempt to reconstruct the meanings of USC hints at different polysemous concepts that, when applied in relation to USC, create dilemmas as regards their meaning since they are also associated with the political sense of University and education. Furthermore, different attributions of meaning can hinder an identification of the ideological positions which support and give identity to certain concepts, such as pertinence, management, University autonomy, academic freedom and the mission of University, among others.

On this line, the dilemmas now concern the mission of University and the purpose of University management: is the goal to have a work methodology which determines political and economic aims and defines what steps to take so as to achieve that purpose? Or is management thought of as an end in itself concerning control, verification and accountability? In any case, autonomy and academic freedom have both stern supporters and opponents on each end. There are those who see in these concepts the possibility of keeping University away from any external influence, but also those who think that they make the link with society possible.

Ultimately, each proposition externalizes underlying ideologies and political conceptions, whether in their macro or micro-context of development. The strongest challenge is probably to leave behind the surface so as to reach what lies in the depths of each concept, i.e., being able to transcend a clash of ideas based on what "we assume" the other person supports and, in turn, identifying the actual ideology present in the configuration of a particular discourse, regardless of the terms used.

Hannah Arendt (2005, p. 97) expresses that: "If, however, we understand politics to mean a global dominion in which people appear primarily as active agents who lend human affairs a permanence they otherwise do not have, then this hope is not the least bit utopian". Universities and university agents have much to offer by means of contributions which enable taking root in the ideological and political spheres. From the perspective of USC, thought as an expression of the social function of University, there are emerging lines of action intended to democratize access, curricula, research and the transference of knowledge. Furthermore, through USC we can strengthen and expand the concept of extension, especially in terms of the position held on non-University agents; of working on what makes us citizens, on what, at present, determines inclusion and exclusion, and on how collective values operate in a society based on individual competence and economic values.

Another interesting factor worth stressing is HEls' practices from the perspective of SC. This paper does no examine such dimension in detail, since the analysis focuses on the theoretical conceptions and principles behind USC. Nevertheless, there is plenty of bibliographic material available which focuses 
on the analysis of practices based on principles related to SC and carried out in different academic contexts. This fact strengthens the idea that we are working on the definition of a field still under construction and that there is much to do and conceptualize about. On the other hand, this is a field constructed in the academic sphere, but also through management and agents' practices. In this regard, it differs from other fields in that it is much more influenced by practices, institutional decisions and geopolitical aspects. As this kind of analysis moves forward, it will certainty contribute to a greater specification of the field and the meaning of USC. Additionally, it may give visibility to how the calling for action made during the CRES and the WCHE was channeled, to the concrete lines of action implemented by HEls and to what extent institutional public policies were transformed as regards teaching, research and extension.

It would appear that the present challenges of $\mathrm{HE}$, in view of the cultural consequences of globalization and changes in social structures, lead to a place where there is nothing else to say or do. Nonetheless, since the $1918 \mathrm{Re}-$ form model was inscribed in Latin American universities, it has called us, even today, to be part of a progressive change of State and society which, based on the defense of democratic life and peace, enables the reconstruction of solidarity-based ties and generates a new appreciation of the Latin American identity and cooperation between the countries of our region.

Assume USC as related to the social function of universities contributes to granting HE social legitimacy while enabling the organization of university social processes so that actions are sustained by that which is specific of a discipline and by the relation of such discipline with the professional, cultural and social context. In this way, University keeps its essence and, based on its autonomy, it builds exchange processes with society.

\section{Bibliographical Notes}

(1) This article partially communicates the Final Work carried out to obtain the degree of Specialist in High Education Policies and Management awarded by Rosario National University, approved on May 28, 2014. Additionally, it contributes to the definite formulation and development of the Doctoral Thesis Plan: "La formación de profesionales desde la perspectiva del compromiso social universitario" (The education of professionals from the perspective of university social commitment), to be carried out within the PhD in Education of Experimental Sciences, College of Biochemistry and Biological Sciences, Litoral National University (UNL). The fieldwork for the Doctoral Thesis will be carried out within the Project "La formación de profesionales desde la perspectiva del compromiso social. Huellas y olvidos", (The education of professionals from the perspective of university social commitment. Marks and omissions) approved by UNL in the COURSE OF ACTION FOR RESEARCH AND DEVELOPMENT, "R\&D Program Oriented to Social and 
Productive Problems". 2012 Call.

(2) As the view of Miguel Rojas Mix was taken into consideration during the analysis of the contributions made at the Conference of Rectors, this section does not analyze it in detail.

(3) This Research Project concerns "University Social Commitment" and develops under the scope of the Institute for Studies and Training of the Argentinian National Federation of University Teachers (CONADU), which has an Area of Research whose subject of study is the University.

(4) Additionally, the authors place the origins of the social role of University in the 1918 University Reform.

(5) The authors mention the impacts expected from the application of USR according to Vallaeys' words: Socially responsible management of the organization and its resources; of academic and pedagogic education; of the production of knowledge and promoted epistemological models; and of the participation in SHD. Torres Pernalete \& Trápaga Ortega (2010:79).

\section{Bibliographic References}

- Arendt, H. (2005). The Promise of Politics, New York: Schocken Books. TN: in the original Spanish article, quoted from: Arendt, H. (1997:50). ¿Qué es política?, Barcelona: Paidós.

- Cecchi, N., Lakonich, J., Pérez, D. \& Rotstein, A. (2009). El Compromiso Social de la Universidad Latinoamericana del Siglo XXI: Entre el debate y la acción, IEC-CONADU y ADUM. From: http://www.iecconadu.org.ar/images/LIBRO $\% 203 \% 20$ El\%20 compromiso\%20Social\%20FINAL.pdf

- Conferencia Mundial de Educación Superior (1998): Comunicado Final. From: http://unesdoc.unesco.org/images/0011/001163/116345s.pdf

- Conferencia Regional sobre Políticas y Estrategias para la Educación Superior en América Latina y el Caribe (1996). Proclamación final. From: http://www.rau. edu.uy/docs/havdecs.htm

- Congreso Internacional de Rectores Latinoamericanos y Caribeños (2007). Declaración final. From: http://www.unesco.org.ve/dmdocuments/3encuentro/ DeclaraCongRectores_Esp.pdf.

Declaración final. From: http://www.cres2008.org/es/index.php.

- De la Cruz Ayuso, C. \& Sasia Santos, P. (2008). La responsabilidad social de la universidad en el proyecto de construcción de una sociedad. Revista Educación Superior y Sociedad. El movimiento de responsabilidad social de la universidad: una comprensión novedosa de la misión universitaria, 13(2). From: http://ess.iesalc.unesco.org. ve/index.php/ess/issue/view/5

- De Sousa Santos, B. (2005). La Universidad en el Siglo XXI. Para una reforma democrática y emancipadora de la Universidad, México: Centro de Investigaciones Interdisciplinarias en Ciencias y Humanidades, Universidad Nacional Autónoma de México. 
- Garcia Guadilla, C. (2008). El compromiso social de las universidades [lectronic version]. Cuadernos del Cendes, 25(67), 129-134.

- Margetic, A. \& Suarez, V. (2006). La función social de la Universidad. Consideraciones acerca de los Estatutos de las Universidades Nacionales. Remedios de Escalada: UNLa.

- Regional Conference on Higher Education in Latin America and The Caribbean. (2008). Declaration. From: http://www.iau-hesd.net/sites/default/files/documents/2008_-_declaration_of_the_regional_conference_on_higher_education_in_ latin_americe_and_the_carabean_fr.pdf. TN: in the original Spanish article, quotes from: Conferencia Regional de Educación Superior en América Latina y el Caribe $(2008: 1,6,7)$.

- Rojas Mix, M. (2007). El Compromiso Social de las Universidades de América Latina y el Caribe. From: http://ess.iesalc.unesco.org.ve/index.php/ess/article/ view/46/33

- Saravia, F. \& Escobar, J. (2010). Hacia una democracia socialmente responsable. Una reflexión desde la Universidad Pública. 1st edition, Buenos Aires: Prometeo.

- Torres Pernalete, M. \& Trápaga Ortega, M. (2010), Responsabilidad Social de la Universidad. Retos y Desafíos. 1st edition, Buenos Aires: Paidós.

- Vallaeys, F.; de la Cruz, C. \& Sasia, P. (s, f), Manual de primeros pasos en responsabilización social universitaria. Construyendo ciudadanía en universidades responsables. From: http://www.cyta.com.ar/biblioteca/bddoc/bdlibros/rse/334_ as_ma-nual_rsu_bid.pdf.

- World Conference on Higher Education (2009): The New Dynamics of Higher Education and Research for Societal Change and Development. Comunniqué. From: http://www.unesco.org/fileadmin/MULTIMEDIA/HQ/ED/ED/pdf/WCHE_2009/ FINAL\%20COMMUNIQUE\%20WCHE\%202009.pdf. TN: in the original Spanish article, quote from: Conferencia Mundial de Educación Superior (2009:2-7): Las nuevas dinámicas de la educación superior y de la investigación para el cambio social y el desarrollo. Comunicado Final. From: http://www.unesco.org/education/ WCHE2009/comunicado_es.pdf. 